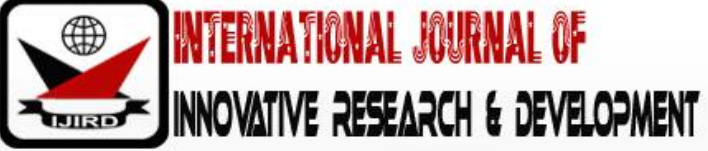

ISSN 2278 - 0211 (Online)

\section{Finland's Forest Culture: Lessons for Kenya}

\author{
Dr.John 0.Kakonge \\ President, Association of Former International Civil Servants of the United Nations, Kenya
}

\begin{abstract}
:
Finland's forestry sector has gone through transformation for more than a century. This paper highlights some of the key factors which have made Finland one of the success stories globally. In comparison with Kenya, it is clear that Finland is very advanced in the field of forestry. Nevertheless, there are lessons which can be learned from Finland which could be useful to improve, modernize and expand the forestry sector in Kenya. These lessons cover such topics as forest culture, forest management plans, logging permits, a forest extension service and increasing forest cover. The paper calls for a strong partnership of key actors in forestry research in Kenya, including a high level of transparency and coordination.
\end{abstract}

Keywords: Forest culture, forest management plans, forest cover, forestry extension service and forestry research

\section{Introduction}

Forests mean different things to different people. For many, forests are a source of firewood; for some, forests are places of spiritual significance, while for others, they are associated with danger and evil; and for many others, forests are vital providers of drinking water for communities or towns. One of the outcome documents of the United Nations Conference on Environment and Development, held in Rio de Janeiro, Brazil, in 1992, the "Non-legally Binding Authoritative Statement of Principles for a Global Consensus on the Management, Conservation and Sustainable Development of All Types of Forests" acknowledges that forests are essential to economic development and the maintenance of all forms of life (United Nations, 1992).

Finland, the subject of this brief paper, is a country that is densely covered with forests. Interestingly, this has not always been the case: the country's forest cover as we know it is the result of deliberate policies of re-afforestation and forest conservation. The conscious move towards such policies did not take place in recent times, however: it was triggered by a consultancy report published as long ago as 1886. The former Finnish President Martti Ahtasaari, in an address to the Food and Agriculture Organization of the United Nations in Rome in 1999, noted that "our first known foreign forest consultant gave us the following questionable appraisal: The Finns have become very skilful in the art of destroying forests'. And furthermore: 'The Finns live in and from the forest, but out of stupidity and greed - like the old woman in the fairy tale - they kill the goose that lays the golden egg'. As a consequence of the report, our first forest law was written in 1886. The statement was simple but effective: the forest shall not be destroyed. In a small country it was easy to realize that if we did not plant when we harvested, we would not have trees in the future." This was turning point for the Finnish forestry sector.

Today, forests make a major contribution to the Finnish national economy. For example, according to Luke (2017), forestry products provided 22 per cent of the total value of Finland's export goods in 2016. This represents 4 per cent of GDP from a sector that employs 65,000 people.

In the case of Kenya, the precise contribution of forests to the economy is hard to determine, because some figures are not reported. This could be as a result of mismanagement and corruption. According to the United Nations Environment Programme (2012), however, the annual contribution of the forestry sector was 3.6 per cent of GDP. The Kenya Forest Service Study of 2010 also notes that forest destruction occurred as a result of incursion into forest areas for agriculture, owing to rural poverty and rapid population growth, unsustainable use (timber harvesting and charcoal burning), poor governance and failure of institutions. The 2018 report of the Forest Taskforce (Government of Kenya/ Ministry of Environment and Forestry, 2018) warns that the remaining forest is being depleted at an alarming rate and that, unless something drastic is done, the country might be converted into a desert, as has already happened in the northern part of the country. It is with this in mind that this brief is looking at Finland, which was categorized as a poor country at the beginning of the nineteenth century and is now a rich one, and also rich in forests.

\subsection{Comparison between Finland and Kenya on Key Forestry Issues}

This paper will provide a brief comparison of forestry issues in Finland and Kenya, focusing on forest culture, forest management plans, an enforcement system, institutional support, forest legislation and forest research. 


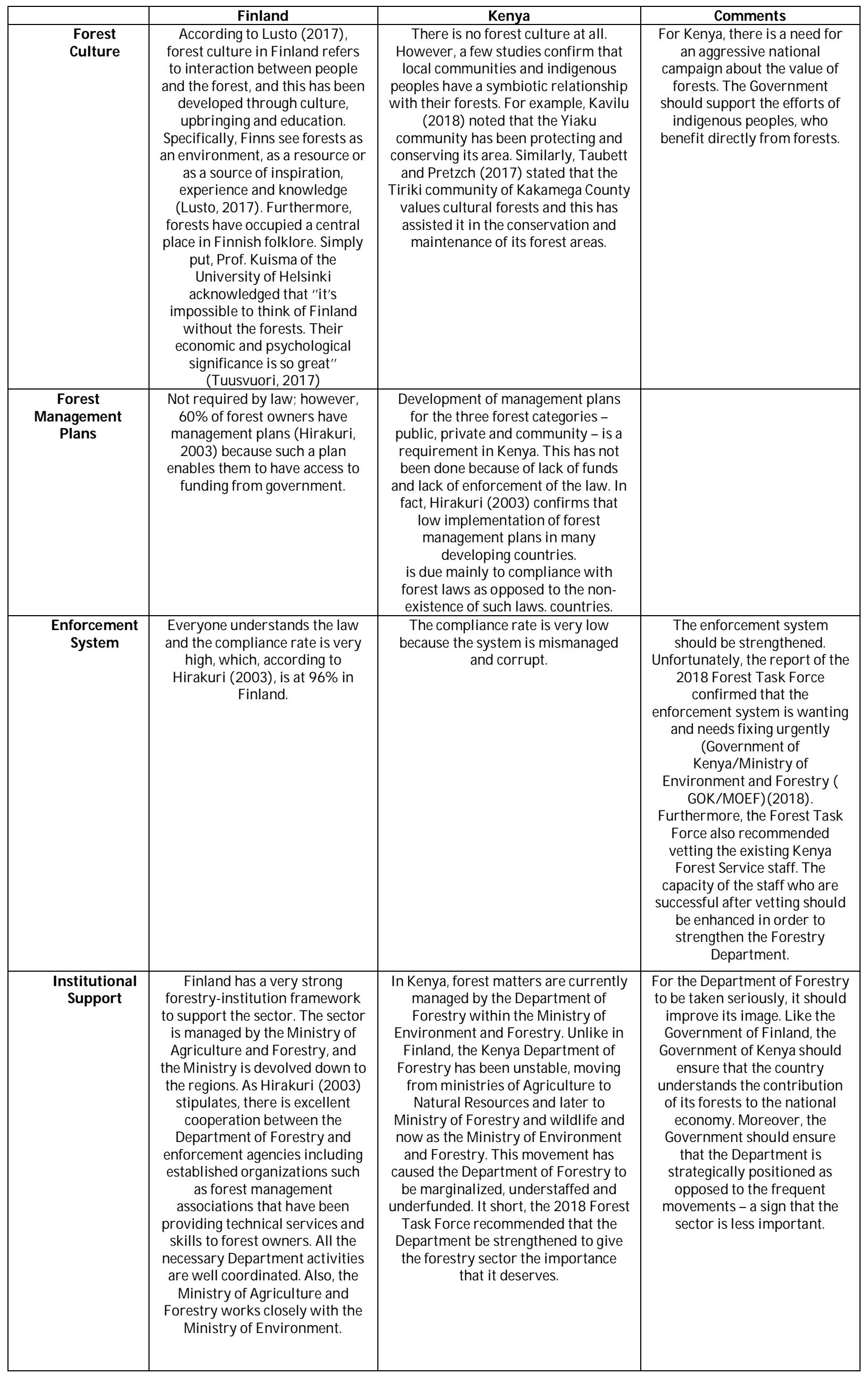




\begin{tabular}{|c|c|c|c|}
\hline & Finland & Kenya & Comments \\
\hline $\begin{array}{c}\text { Forest } \\
\text { Legislation }\end{array}$ & $\begin{array}{l}\text { Finland forest legislation was } \\
\text { passed in } 1886 \text { and was } \\
\text { completely reformed in the } \\
\text { 1990s. Moreover, FAO (2012) } \\
\text { noted that Finland has been } \\
\text { revising its main forest } \\
\text { legislation and regulations to } \\
\text { correspond to international } \\
\text { obligations. Regardless, the } \\
\text { forest law and other related } \\
\text { provisions are adhered to: } \\
\text { specifically, the forests should } \\
\text { not be destroyed nor should } \\
\text { they be used without regard for } \\
\text { regeneration and renewal. }\end{array}$ & $\begin{array}{l}\text { Kenya forest legislation and } \\
\text { regulations have gone through } \\
\text { tremendous changes from colonial } \\
\text { days to the present.According to } \\
\text { Matiru (1999), the legal provision for } \\
\text { the protection and management of the } \\
\text { environment and forests is scattered } \\
\text { in } 77 \text { statutes. Other studies such as } \\
\text { the one for Chebil (2015) argued that } \\
\text { Kenya's law for the sustainable } \\
\text { management and conservation of } \\
\text { forest resources is not comprehensive } \\
\text { in scope and its inadequacy and } \\
\text { efficacy are not satisfactory. }\end{array}$ & $\begin{array}{l}\text { There have been many } \\
\text { amendments in the Kenya } \\
\text { forest laws and regulations. } \\
\text { However, based on the } \\
\text { example from Finland, laws are } \\
\text { useful if they are enforced. This } \\
\text { is the challenge for Kenya, and } \\
\text { it must be addressed if Kenya } \\
\text { wants to save and benefit from } \\
\text { its forest resources. }\end{array}$ \\
\hline Forest Research & $\begin{array}{l}\text { The Finnish research system is } \\
\text { relatively decentralized, with its } \\
\text { many research activities being } \\
\text { conducted by universities, } \\
\text { polytechnics and government } \\
\text { institutes. Moreover, forest } \\
\text { research is moving away from } \\
\text { forest ecosystem-based research } \\
\text { with a focus on growing tree } \\
\text { stands and forest management } \\
\text { towards acustomer-oriented } \\
\text { approach that serves policy and } \\
\text { economic sectors (Ministry of } \\
\text { Agriculture and Forestry( } \\
\text { MOAF), 2007).Funding is mainly } \\
\text { by the Finnish Government and } \\
\text { the remaining funding in recent } \\
\text { years has come from related } \\
\text { government institutions, namely, } \\
\text { the Academy of Finland, Finnish } \\
\text { Funding Agency for Technology } \\
\text { and Innovation( TEKES) and } \\
\text { others. In this connection, of } \\
\text { nine academies of science, the } \\
\text { forestry cluster in Finland is one } \\
\text { of the most important clusters of } \\
\text { expertise (Metla, 2016). }\end{array}$ & $\begin{array}{l}\text { According to Ochuodho and Odera } \\
\text { (2010), forest research in Kenya is } \\
\text { underfunded and lagged behind } \\
\text { funding for all other land uses. This is } \\
\text { partly because the current perception } \\
\text { that the contribution of the forestry } \\
\text { sector to the gross domestic product } \\
\text { (GDP) is insignificant. This has } \\
\text { resulted in a lack of documentation } \\
\text { and analysis and a flagging out the } \\
\text { forest's service functions. } \\
\text { Furthermore, there is no policy } \\
\text { framework on accessing research } \\
\text { information on forestry or related } \\
\text { areas. In July 2018, Kenya scientists } \\
\text { from the agro-forestry and } \\
\text { environmental conservation fields } \\
\text { noted that a great deal of information } \\
\text { lies unused by those who need it } \\
\text { (Musa, 2018). Also, in 2018, the Forest } \\
\text { Task Force recommended that the } \\
\text { capacity of the Kenya Forest Research } \\
\text { Institute be enhanced in order to } \\
\text { develop effective, efficient and up-to- } \\
\text { date research methodologies that } \\
\text { could be deployed within the forestry } \\
\text { sector to upgrade and expand its } \\
\text { activities. }\end{array}$ & $\begin{array}{l}\text { Unlike in Finland, forest } \\
\text { research is underfunded, and } \\
\text { its activities are scattered and } \\
\text { uncoordinated. Therefore, } \\
\text { there is a mismatch between } \\
\text { forest research conducted in } \\
\text { the country and its } \\
\text { contribution to the forestry } \\
\text { sector. Also, as demonstrated } \\
\text { by Finland, forestry research } \\
\text { calls for a partnership of the } \\
\text { key actors: government, } \\
\text { government-related } \\
\text { institutions, academic } \\
\text { institutions and others. }\end{array}$ \\
\hline
\end{tabular}

Table 1

According to all the variables reflected in the above table, Finland is far advanced and one of the leading exporters of forestry products. From the few variables compared, Kenya falls below expectations. However, there some lessons from Finland for Kenya, which are discussed below.

\section{Forest Culture}

Forests have played an important role in shaping the economy and culture of Finland. According to Hirakuri (2003), the Finnish people have enjoyed, and continue to enjoy and respect, non-material values, beliefs, myths and customs that are centred around forests. These are also reflected in their music, literature and paintings. Interestingly, many developing countries, Kenya included, lack any such forest culture. Many developing countries have a negative attitude to forests, which are seen not only as a barrier to development but also as synonymous with disease and terror (Hirakuri, 2003). According to available literature, Kenya, unlike Finland, suffers from heavy deforestation due to illegal logging and charcoal burning, and encroaching human settlement and farming have severely reduced the capacity of forests to provide and store fresh water. These challenges are compounded by illiteracy and poverty. Simply put, the main message from Finland for Kenya is the importance of an appreciation for and protection of the remaining forest cover. The idea of a forest culture should be propagated.

\section{Forest Management Plans}

Forest management plans should detail the measures which the industry takes during and after harvesting, including steps to promote a healthy and sustainable forest. In some countries, such as Brazil, a forest document is simply a document that an organization must submit to the authorities to obtain a permit to harvest timber. In Finland the forest management plan is prepared by the responsible government agency, which has no commercial interest in the outcome of the forestry operations, which is clearly an advantage. Given that this agency is independent, the plans that it recommends would be expected to be ecologically sound and environmentally sustainable (Hirakuri, 2003). Bambo (2010) confirms the view of the Kenya Forests Working Group (KFWG) that the government should increase its financial allocation to the Kenya Forest Service to develop sustainable forest management plans and carry out nationwide recruitment of foresters and forest guards to patrol extensive forest areas. This has yet to be done and the Forest Taskforce, in its 2018 report, 
found that forest resources are poorly and inefficiently managed. In short, the Kenya Forest Service should develop and prepare transparent and independent forest management plans.

\section{Logging Permits}

In Finland the Forestry Act does not stipulate the need for a logging permit. The Act does, however, require forest owners to present a document equivalent to a permit application detailing their planned logging operations, the regeneration method, planting and preservation of the biodiversity of the forests (Hirakura, 2003). In many developing countries the authorities require a logging permit and the process is slow, complicated and fraught with corruption. For example, in Kenya, the Forest Taskforce in its 2018 report found that the Kenya Forest Service changed from open tendering to an allocation procedure for awarding and granting timber logging rights to saw millers. The taskforce found the current system to be unfair, inadequate, inappropriate and open to abuse. In view of this, Kenya should go back to using the open tender system which is transparent and above board.

\section{Forestry Extension Service}

In Finland, the forestry extension service is the backbone of the sector and has contributed to the attainment of sustainable forestry. In many developing countries, such as Kenya, forestry extension services either do not exist or have collapsed. In Finland, extension services, among others, offer advice on good management practices and sustainable forestry management, including compliance with the law and practical training for forest owners. Hirakura (2003) confirms that in countries such as Bolivia, Brazil and Costa Rica, forestry owners and workers have not received any information or training from extension services because they simply do not exist. Where extension services do exist, however, their role seems to have been to collaborate with logging companies, thus permitting them to destroy forests with impunity. There is no doubt that re-establishing, strengthening forestry extension services in Kenya could rescue the forests, which are being depleted at an alarming rate, provided the objectives, and aims of forest restoration are clearly stated and understood.

\section{Increasing Forestry Cover}

According to FFA (2014), Finland is one of the most densely forested countries in Europe with coverage of 71 per cent of the total land area. This is due to its efficient forest management, rehabilitation of poorly growing forests, effective drainage systems, and the growing density and fertility of forests, resulting in an increase of the forest stalk growth (FFA, 2014). In this context, the Kingdom of Bhutan has also done fairly well. Its constitution includes a provision which stipulates that 60 per cent of the country's land must be maintained under forest cover at all times in order to secure ecological balance (WFC, 2011). Bhutan has the highest proportion of forest cover, at about 69 per cent, and protected area and biological corridors (51.44 per cent) of any Asian country (WFC, 2011).

Another country making progress with forest density, according to the World Future Council (2011), is Rwanda. Its 2004 National Forest Policy, which aims to make forestry the bedrock of its economy, saw the country embark on massive reforestation involving indigenous species, local population, agroforestry and education about forestry management with a variety of ecological, social and economic benefits. Thus, if the trend continues, Rwanda will increase its forest cover to 30 per cent of the total land mass by 2020 and beyond. In the case of Kenya, McConnell (2009) argues that the forest cover is estimated at 7.4 per cent of the total land area, a far cry from the recommended global minimum of 10 per cent.

Unlike Finland, Kenya does not have the sustained political will and support to ensure an essential increase in its forest cover. Clearly, to draw one important lesson from Finland andfrom the observations made in recent studies, we need to focus on implementation of the Forest Act of 2016, which, among other things, operationalizes tree planting to increase the forest cover.

\section{Partnership and Collaboration in the Forestry Sector}

Finland has expanded and continues to expand partnerships with respect to the forestry sector. Interestingly, most of the Finland forests are owned by private individuals and families who own more than 2 hectares. The remaining forests are owned by the State (FRI, 2016). Forest ownership is coordinated by both the Finnish Ministry of Agriculture and the Finnish Forest Association. As noted by Hirasuka (2013), private individuals played an important role in the forest timber supply, accounting for $75 \%$ of the wood used by the industry. In this connection, the forest policies have been implemented to support private small forest owners. Moreover, the partnerships between Finnish research institutions and the Department of Forestry have resulted in a high level of know-how, innovation, new developments, top-level research, versatile education, and utilization of research data (Metla, 2017). Furthermore, Finland has established a strategic Centre for Science, Technology, and Innovation (SHOKS) mainly to promote cooperation and communication between companies, universities, research institutions and funding organizations operating in Finland (Metla, 2017). Simply put, the Finnish forest industry is very sophisticated, with strong partnership and collaboration between and among key factors such as government, research, industry, unions, land owners, environmental and recreational NGOs and academia (EU, 2016). In contrast, Kenya needs to establish a sustainable partnership between and among key actors involved in the forestry sector. Unfortunately, GOK/ MOEF (2018) confirmed that the Department of Forestry suffers from inadequate coordination among the various agencies of the government., resulting in duplication of roles and inefficient management of forest resources. By and large, Nogueron (2013) stipulated that governments, especially of developing countries, should recognize the rights of local communities and indigenous peoples not only by involving them in the decision-making processes that affect the forests on which they directly depend for their livelihoods but also by playing a role as effective leaders and partners in forest conservation. 


\section{Conclusion}

From the foregoing, sustainable forestry management is clearly a collaborative effort. It calls for support from everyone, including communities, government officials, politicians and logging companies. Destroying forests with impunity, without giving thought to tomorrow or the future, is selfish, greedy, inconsiderate of others and perpetuates poverty. If you cut down trees for charcoal, then you must think of replacing them so that you can harvest tomorrow. That is the Finnish forest culture. Furthermore, the national Constitution of Finland provides the framework by which forests must be respected and protected. That is what has made Finland great in the field of forestry and this also is the case with Bhutan. Whatever the constitutional safeguards, however, the idea of a forest culture must also be propagated.

Sadly, at the rate Kenya is going, it will not reach it is ambition of having forest cover of 10 per cent or more of its land mass by 2030 and beyond. Impunity and corruption, in particular of senior government officials who are supposed to be protecting the forests, should not be tolerated. The culprits must be punished and nationwide tree-planting should aggressively continue to be encouraged. It is equally important that seedlings provided to people or communities should be drought-resistant and should be of quick-growing species. The spirit of the Green Movement introduced by the late Nobel Prize laureate Wangari Maathai should be harnessed to this end.

Another lesson to be drawn from Finland's experience is that the Finnish forestry extension service continues to provide critical advice in the management of their forests. The recent report of the Kenya Taskforce recommended that the government should vet the current Kenya Forest Service personnel with the aim of identifying competent and suitable people who are committed to the service. This would eliminate corruption, instil an ethical culture and restore public confidence in the Forest Service. As in Finland, the Kenya Forest Service should appoint inspectors to support the field officers and ensure that they are doing their work. Communities which live in or near forests or which depend on forests and others should be made fully aware of the need for sustainable forestry management, and of the importance of forestsin the areas of climate change, water towers, prevention of soil loss in hilly or mountainous areas, their contribution to GDP, and job creation.

The overall message from Finland is that sustainable forest management rests on good governance and public participation. This is in line with the observation by Tomi Salo (Finnish Forest Industries Federation): "good forest management is the basis for profitable forestry and the growth of wood-based economy".

\section{*The views, thoughts and opinions expressed in this paper belong solely to the author and not necessarily to AFICS-Kenya.}

\section{References}

i. Ahtisaari, M. (1999). Speech on Sustainable Forest Management in Finland: Its development and possibilities. Available from www.fao.org/ tempref/ docrep/ fao/ x3989e/ x3989e09.pdf.

ii. Bambo, J. (2018). "Understanding issues affecting Kenya's forest cover". Available from www.standardmedia.co.ke/ article/ 2001273025/ understanding-issues-affecting-kenya-s-forest-cover-ahead-ofinternational-day).

iii. Chebil, J. (2015). Forest Management and Conservation in Kenya: A Study of the Role of Law in the Conservation of Forest Resources. Unpublished thesis for the Doctor of Laws degree, University of South Africa. Available at http:/ / uir.unisa.ac.za/ bitstream/ handle/ 10500/ 20093/ thesis_chebii jk.pdf?sequence=1 \&isAllowed=y.

iv. Finnish Forest Association (FFA) (2016). Finnish forest resources. Available from https://smy.fi/ en/ forestfi/ forest-facts/ finnish-forests-resources/ .

v. Finnish Forest Research Institute (2016). Forest ownership, 8 January 2016. Available at https:/ / smy.fi/ en/ forestfi/ forest-facts/ finnish-forests-owned-by-finns/ .

vi. Food and Agriculture Organization of the United Nations (FAO) (2012). Finnish Policies, Institutions and Programmes. Available at http:/ / www.fao.org/ forestry/ country/ 57479.en/ fin.

vii. Government of Kenya/ Ministry of Environment and Forestry (2018). "A Report on Forestry Resources Management and Logging Activities in Kenya: Findings and Recommendations". Available from www.slideshare.net/ starwebmaster/ forest-taskforce-report.

viii. Heino, J. and Karvonen, J. (2003). "Forests-an intergrated part of Finnish life". Available from www.fao.org/ docrep/ pdf/ 005/ y9882e/ y9882e02.pdf.

ix. Hirakuri, S. R. (2003). Can Law Save the Forest? Lessons from Finland and Brazil. Center for International Forestry Research, Indonesia. Available from www.cifor.org/ library/ 1210/ .

x. Kavilu, S. (2008). A forest of their own: The Yiaku as Kenya's model forest stewards. Mongbay Series: Indigenous Peoples and Conservation, 26 November 2018. Available at https:// news.mongabay.com/2018/11/a-forest-oftheir-own-the-yiaku-as-kenyas-model-forest-stewards/

xi. Kenya Forest Service (2010) Walking the Talk: Corruption Perception Baseline Survey.Finnish Forest Association (FFA) (2016). Finnish forest resources. Available from https://smy.fi/ en/ forest-fi/forest-facts/ finnish-forestsresources/.

xii. Luke National Resources Institute Finland (2017). National Forest Inventory, Statistical Services, Finland. Available fromwww.luke.fi/ en/ news/ forest-resource-data-now-available-statistical-services-natural-resources-institutefinland/.

xiii. $\quad$ Lusto (2017). The forest relationship in Finland. Available at: https:// wiki.aineetonkulttuuriperinto.fi/ wiki/ The_forest_relationship_in_Finland. 
xiv. Matiru, V. (1999). Forest Cover and Forest Resources in Kenya: Policy and Practice. Available at http:// cmsdata.iucn.org/ downloads/ forestcover.pdf.

xv. McConnell, T. (2009). "Kenya's Mau Forest under threat". Global Post. 25 July 2009. Available from www.pri.org/ stories/ 2009-07-25/ kenyas-mau-forest-under-threat"ttps:/ / www.pri.org/ stories/ 2009-0725/ kenyas-mau-forest-under-threat.

xvi. Metla (2012). State of Finland's forests 2012: Criterion 6 socio-economic functions. Luke. Available at http:// www.metla.fi/ metinfo/ sustainability/ c6.htm.

xvii. Ministry of Agriculture and Forestry (2007). State of Finland's Forests 2007: Based on the Criteria and Indicators of Sustainable Forest Management. Available at http://www.metla.fi/julkaisut/muut/ state-of-finlands-forests2007.pdf.

xviii. Musa, P. (2018). Allow sustainable forest use based on science, experts say. 13 August 2018. Daily Nation. https:/ / www.nation.co.ke/ health/ Allow-sustainable-forest-use-based-on-science/ 3476990-47104929l8qlsz/ index.html.

xix. Nogueron, R. ( 2013). 5 lessons for sustaining global forests, 18 March 2013. World Resources Institute. Available at https:/ / www.wri.org/ blog/ 2013/ 03/ 5-lessons-sustaining-global-forests.

xx. Ochuodho, T.O. and J.O. Odera (2010). Forest Profession: Missing Link or Gap in Training, Education, Research and Technology Dissemination? Available at https:/ / docplayer.net/ 61806519-Forest-landscape-and-kenya-s-vision2030-forest-landscape-and-kenya-s-vision-editors-d-o-ogweno-paul-opanga-and-alex-o.html

xxi. Taubett, B and Pretzch,J (2007) Cultural Influence of Forest Perception and Forest Use among the Tiriki Community in west Kenya. http:/ / www.tropentag.de/ 2007/ abstracts/ full/ 476.pdf

xxii. Tuusvuori, A. (2017). Finland's forests gave it its prosperity. What will the country do in a post-paper world? 22 September 2017. University of Helsinki. Available at https:/ / www.helsinki.fi/ en/ news/ society-economy/ finlandsforests-gave-it-its-prosperity.-what-will-the-country-do-in-a-post-paper-world.

xxiii. United Nations (1992). Report of the United Nations Conference on Environment and Development, Annex III (A/ CONF.151/ 26 (Vol. III)). Available from www.un.org/ documents/ ga/ conf151/ aconf15126-3annex3.htm.

xxiv. United Nations Environment Programme (2012). Deforestation costing Kenya Economy Millions of Dollars Each Year and Increasing water shortage risk.

https:/ / www.unenvironment.org/ news-and-stories/ press-release/ deforestation-costing-kenyan-economymillions-dollars-each-year-and

xxv. World Future Council (WFC) (2011). Forest Policies from six countries shortlisted for Future Policy Award. Press Release, New York, 5 July 2011. Available from www.worldfuturecouncil.org/forest-policies-six-countriesshortlisted-future-policy-award/ . 